\title{
Feature
}

From the National Academies

\section{Evolution Education across the Life Sciences: Making Biology Education Make Sense}

\author{
Cynthia A. Wei, ${ }^{*}$ Paul M. Beardsley, ${ }^{\dagger}$ and Jay B. Labov ${ }^{\ddagger}$
}

${ }^{*}$ Christine Mirzayan Science \& Technology Policy Fellowship Program, National Academy of Sciences, Washington, DC 20001; ${ }^{\dagger}$ Center for Excellence in Mathematics and Science Teaching, Biological Sciences Department, California State Polytechnic University, Pomona, CA 91768; ₹National Academy of Sciences and National Research Council, Washington, DC 20001

Nothing in biology makes sense except in the light of evolution.

-Theodosius Dobzhansky (1973)

In 1996, elementary school students in Marshall County, Kentucky, were ordered to turn in their science textbooks. After the books were returned, students found two pages of each textbook were glued together. The pages were glued by order of the school superintendent because they contained a scientific explanation of the origin of the universe but not a biblical account. But what if others tried to avoid teaching evolution using this tactic? Could they? At the October 25-26, 2011, convocation, Thinking Evolutionarily: Evolution Education Across the Life Sciences, organized by the National Research Council's (NRC) Board on Life Sciences and the National Academy of Sciences (NAS) in Washington, DC, Robert Pennock (Michigan State University) argued that no one should think they can simply glue together a few pages or a chapter of a textbook and be able to avoid the topic of evolution; if modern biology is taught as it should be, references and connections to the fundamental concepts of evolution should be seen throughout the textbook and in every topic presented in the course. He issued the following challenge to the participants of the convocation: "How can we make sure that you couldn't do this unless you [were willing to] glue the whole textbook together?"

DOI: $10.1187 /$ cbe.11-12-0111

Address correspondence to: Jay B. Labov (jlabov@nas.edu).

(C) 2012 C. A. Wei. et al. CBE-Life Sciences Education (C) 2012 The American Society for Cell Biology. This article is distributed by The American Society for Cell Biology under license from the author(s). It is available to the public under an AttributionNoncommercial-Share Alike 3.0 Unported Creative Commons License (http://creativecommons.org/licenses/by-nc-sa/3.0).

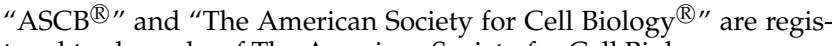
tered trademarks of The American Society for Cell Biology.
The life sciences community accepts the centrality of evolutionary concepts and processes for understanding the unity, diversity, and history of life. Yet the study of evolution has long been a source of contention in public schools and in public and political discourse in many parts of the United States. This is partly because many people do not understand the principles of evolution or the nature, processes, and limits of science more generally (National Academy of Sciences and Institute of Medicine, 2008).

Contributing to the problem is the way in which evolution is typically taught. It is often presented as one discrete topic among many in the biology curriculum, leading to the false impression that it can be isolated or even removed from biology courses (e.g., Nehm et al., 2009). In fact, many teachers avoid teaching evolution by leaving the topic until the end of a busy course, where it can often simply be skipped. A more appropriate way to teach evolution and to teach biology is to make clear to students how the concepts and principles of evolution are fundamental to modern science (in biology and many other disciplines) and are the integrating framework that guides biologists' questioning and understanding of the natural world.

\section{A CONVERGENCE OF INITIATIVES CALLING FOR EVOLUTION EDUCATION}

In response to these issues, the National Science Education Standards (NRC, 1996) call for teaching about evolutionary principles throughout the $\mathrm{K}-12$ curriculum with concepts that are grade-appropriate and that build upon earlier concepts. A new publication from the NRC (2011), which serves as the framework for the development of the next generation of $\mathrm{K}-12$ science standards, reinforces and extends earlier 
recommendations about the importance of integrating evolutionary concepts with others in the life sciences.

Members of the science education community also emphasize the importance of weaving evolutionary principles into life sciences curricula at all levels, both pre- and postsecondary. This growing recognition of the central role of evolution in biology is reflected in several recent initiatives, revisions, and assessments by a spectrum of national organizations, including the American Association for the Advancement of Science (AAAS; 2011), College Board (2011), Association of American Medical Colleges (AAMC), Howard Hughes Medical Institute (HHMI; AAMC and HHMI, 2009), National Evolutionary Synthesis Center (NESCent), National Science Foundation (NSF), and a number of disciplinary and professional societies. ${ }^{1}$

For example, the College Board (2011) is currently restructuring its Advanced Placement (AP) Biology course for high school students based on recommendations from the NRC (2002) and has announced that evolution will be the first of four core ideas around which the new course will be structured. (The restructured AP Biology course is scheduled to be implemented during the 2012-2013 school year.) In 2009, AAMC and HHMI jointly published Scientific Foundations for Future Physicians, which also establishes understanding evolution as a key competency for students who are interested in medical careers. Finally, Vision and Change in Undergraduate Biology Education (AAAS, 2011), a national initiative sponsored by several national organizations and agencies, including NSF, AAAS, HHMI, and the National Institutes of Health (NIH), also highlights evolution as one of five overarching core biological concepts that all undergraduates should understand in order to be biologically literate. With so many national organizations drawing attention to the fundamental importance of evolution to life sciences education, now is an opportune time for biology educators to make evolution a central theme in all life sciences courses.

\section{DEVELOPING A STRATEGIC PLAN FOR THE THINKING EVOLUTIONARILY INITIATIVE}

With the growing chorus of calls to incorporate evolution as a central theme in biology teaching comes the need for a strategic plan to coordinate these efforts effectively and sustainably across institutions and across levels of the education system. It is also critical to develop and widely disseminate examples of evidence for evolution and "evolutionary thinking" that postsecondary and $\mathrm{K}-12$ faculty can easily access, edit, and incorporate into their courses (for examples, see Box 1).

The groundwork for the national initiative Thinking Evolutionarily was laid during several meetings hosted by NESCent from 2007-2008. This series of meetings (Evolution Across the Curriculum) generated a consensus on the beginnings of a strategic plan for coordination and action over the next 2-3 yr. The three key components of the plan include:

1. Collation of existing and development of new online teaching/learning resources that will enable faculty who teach survey courses in the life sciences to help their

${ }^{1}$ Statements from more than 100 disciplinary and professional societies have been compiled by the National Center for Science Education and are available at http://ncse.com/media/voices/science.
Box 1. Selected examples of teaching materials currently available that help students develop an understanding of evolution

1. Understanding Evolution website, University of California Museum of Paleontology (http:/ / evolution.berkeley.edu): Includes a section with teaching resources and "teacher's lounges" (K-12 through undergraduate levels). Below are two examples of the resources offered:

- Evolution Misconception Diagnostic (http://evolution. berkeley.edu/evolibrary/teach/evo_misconceps_diagnostic .pdf): Diagnostic tool containing a set of 12 questions (and answers) for uncovering common misconceptions about evolution.

- Evolution Connection: Krebs Cycle (http:/ / evolution .berkeley.edu/evolibrary/search/lessonsummary.php? \&thisaudience $=13-16 \&$ resource_id $=429$ ): Short slide set explaining the uniformity of the Krebs cycle across all life forms using evolutionary theory (appropriate for undergraduate introductory biology courses).

2. NIH Curriculum Supplement on Evolution and Medicine for grades 9-12 (http:/ / science-education.nih.gov/ customers.nsf/HSEvolution.htm): Contains $2 \mathrm{wk}$ of lessons that are easily integrated into curricula and that are aligned to national and state standards.

3. HHMI's BioInteractive website (www.hhmi.org/ biointeractive/evolution/index.html): Features several videos on the topic of evolution and accompanying classroom activities.

4. BioQuest Curriculum Consortium (http://bioquest.org/ bedrock/problem_spaces): Contains a number of investigations and "problem spaces" that enable students to interact with data and develop their own evolutionary explanations. For example, the HIV problem space contains data from a published study on HIV evolution within individual patients (http:/ /bioquest.org/ bedrock/problem_spaces/hiv).

5. PBS Evolution website (www.pbs.org/wgbh/evolution/ index.html): Includes a multimedia library with video clips and Web activities. Other resources for high school teachers include online professional development courses, such as Online Course for Teachers: Teaching Evolution (www.pbs.org/wgbh/evolution/educators/ course/index.html:).

6. Teaching About Evolution and the Nature of Science, NAS (www.nap.edu/catalog.php?record_id=5787:): Includes sample activities for teaching about evolution and the nature of science. For example, there are activities investigating fossil footprints and population growth that teachers can use to introduce principles of evolution. Background information, materials, and step-by-step presentations are provided for each activity.

7. Evolution and the Nature of Science Institutes ENSIweb www.indiana.edu/ ensiweb/: A collection of classroom-tested lessons for middle and high school teachers that provides interactive experiences concerning the nature of science and evolution, as well as curriculum strategies.

NAS and NRC do not endorse specific external products or initiatives. The examples provided here were selected by the authors.

students employ and apply "evolutionary thinking and analysis" to all topics discussed during the course.

2. Workshops for biology faculty teaching at both the secondary and postsecondary levels during meetings of professional organizations and disciplinary societies in the life sciences to introduce members to these resources and to assist in their adoption. 


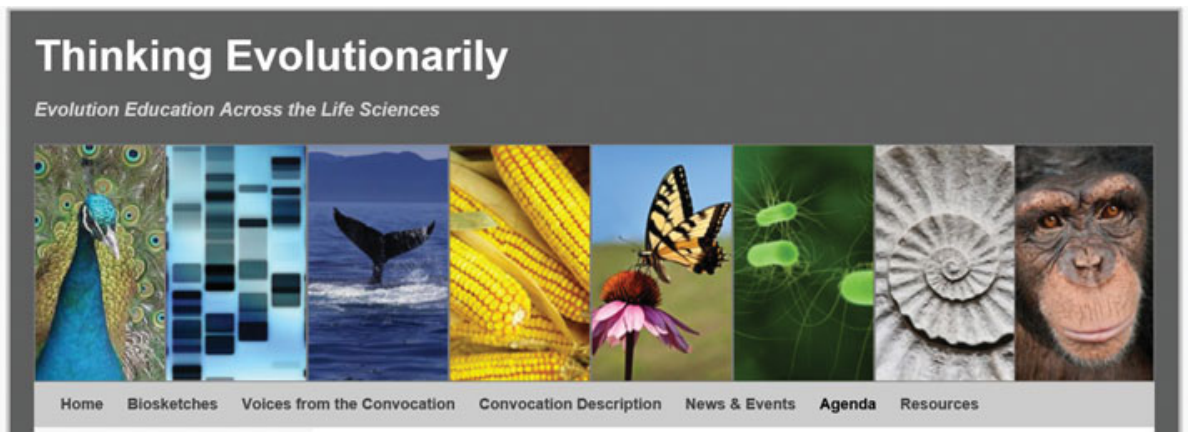

Figure 1. The banner from the NRC/ NAS website for the convocation.
3. A national convocation to be organized and hosted under the auspices of the Board on Life Sciences of the NRC and NAS that would bring together stakeholders, especially professional society representatives, who are critical to the success of this effort, but who too rarely communicate-let alone collaborate- -with one another.

\section{THE THINKING EVOLUTIONARILY CONVOCATION}

Acting on the third element of the strategic plan, a national convocation was planned and conducted according to the NRC workshop processes by NRC/NAS staff and an ad hoc committee appointed by the chair of the NRC. The committee, chaired by Dr. Cynthia Beall, Professor of Anthropology at Case Western Reserve and a member of the NAS, included seven members with deep and diverse expertise in evolution education, who represented diverse stakeholder groups, including science and science education faculty, professional societies, curriculum developers and researchers, and federal agencies $^{2}$ (see also Figure 1). courses. They are terminal courses, the last time in students' formal education when they learn biological or other science content.

On October 25 and 26, 2011, the Thinking Evolutionarily Convocation was held in Washington, DC, at the Carnegie Institution for Science, and brought together participants with diverse experiences in evolutionary science and education from key sectors, including university faculty, high school teachers, public and private funding agency representatives, curriculum developers, and education researchers. The convocation also brought together representatives from 21 professional societies, who provided crucial links to the science and science education communities (see Table 1). Sponsorship of the event was provided by the Burroughs-Wellcome Fund, the Carnegie Institution for Science, the Christian A. Johnson Endeavor Foundation, NAS, and NSF (through a Research Coordination NetworkUndergraduate Biology Education grant to Oklahoma University). Details about the Thinking Evolutionarily Convocation, including the agenda, information about the organizing committee, presenter and panelist biosketches, and a

Table 1. Professional societies represented at the convocation

\begin{tabular}{|c|c|c|}
\hline Association of American Medical Colleges & Animal Behavior Society & National Association of Biology Teachers \\
\hline American Association for the Advancement & Biophysical Society & National Science Teachers Association \\
\hline of Science & Ecological Society of America & Phycological Society of America \\
\hline American Institute for Biological Sciences & Entomological Society of America & Society for Developmental Biology \\
\hline American Society for Microbiology & Federation of American Societies for & Society for Freshwater Science \\
\hline American Society of Human Genetics & Experimental Biology & Society for Integrative and Comparative Biology \\
\hline American Society of Plant Biologists & Human Anatomy and Physiology Society & Society for the Study of Evolution \\
\hline American Society of Primatologists & National Academies Teacher Advisory & \\
\hline
\end{tabular}

With the input of Gordon Uno, Principal Investigator for an NSF Research Coordination Network-Undergraduate Biology Education ${ }^{3}$ project focused on improving introductory biology, an organizer of the Evolution Across the Curriculum initiative, and a special consultant to the Thinking Evolutionarily project, the committee decided to focus the national convocation on infusing evolution science into introductory college courses and biology courses at the high school level. The decision to focus at these levels was driven by the critical opportunity that introductory-level courses represent: for many students, these courses are not really introductory

\footnotetext{
${ }^{2}$ Committee membership details can be found at: http:// nas-sites.org/thinkingevolutionarily/biosketches.

${ }^{3}$ Additional information about this program is available at www.nsf.gov/pubs/2011/nsf11531/nsf11531.pdf.
}

list of recommended resources for teaching evolution can be found at the Thinking Evolutionarily website (http:// nas-sites.org/thinkingevolutionarily). Video clips and slides of the plenary talks, as well as short interviews with five convocation participants, also can be found on the website.

\section{CONVOCATION PRESENTATIONS, PANELS, AND DISCUSSIONS}

We provide here a brief overview of the convocation, although not in chronological order. This article serves as a prelude to a more detailed, internally reviewed, summary report that NAS will release around March 2012. The comprehensive report about the convocation will be available for free downloading from the website of the National Academies Press (http://nap.edu). 


\section{Box 2. Voices from the Convocation ${ }^{4}$}

Question: What does it mean to "think evolutionarily" and why is this important?

Every structure, every function that we study in biology has a history to it, so as I'm teaching biology and as I'm asking my students to consider what we are studying, there's always this question behind everything we study about "where did that come from?," "what's its past history?"..."is there a record to that?," "what do we know about its genetic basis?" It's all Thinking Evolutionarily.

Northwest School, Seattle, WA

$$
\text { -Mark Terry, Chair, Science Department, }
$$

Thinking Evolutionarily has to do with using evidence to understand the world around us... What thinking evolutionarily means is that we consider the evidence about how variation is important, how inheritance is important, how populations can change in their behaviors as well as how they look.

California, Riverside, $C A$

$$
\text { -Marlene Zuk, Professor, University of }
$$

Thinking Evolutionarily is important for biology because everything we study in biology is a product of its history... the only way we have to be able to understand or make predictions in biology is to take that evolutionary history into account.

Austin, and member of NAS

$$
\text { -David Hillis, Professor, University of Texas, }
$$

\section{Thinking Evolutionarily: Why Is This Important?}

The convocation opened with a session titled The Case for Thinking Evolutionarily. Gordon Uno (University of Oklahoma) and Judy Scotchmoor (University of California, Berkeley) articulated their perspectives on why a national initiative to infuse evolutionary thinking throughout the life sciences is needed and why now is the time to act. They also provided an overview of various efforts that have laid the groundwork for the Thinking Evolutionarily initiative. These include the national initiatives described earlier, as well as work of NESCent and the well-known websites Understanding Evolution (see Box 1) and Understanding Science (http://undsci.berkeley.edu), managed by Scotchmoor and sponsored by the University of California, Berkeley; American Institute for Biological Sciences (AIBS); and NESCent. As Uno pointed out, major science education reform movements all emphasize the need to organize around major themes and core concepts and "for biology, evolution is that."

The importance of thinking evolutionarily was reiterated on the second day by Robert Pennock and Bruce Alberts. In his plenary talk, "Moving Evolution Education Forward: Why Evolution and Evolutionary Thinking Are Integral Components of Molecular Biology of the Cell," Bruce Alberts, editor of Science magazine and former NAS president, described the evolution of his own understanding of cell biology over several decades of research and explained how evolution plays a role in helping researchers to understand the "extreme sophistication of cellular mechanisms." Alberts also spoke broadly and passionately about science education and argued that it is critically important to redefine science

${ }^{4}$ Full interviews are available at: http://nas-sites.org/ thinkingevolutionarily/from-the-participants. education with a focus on the processes of science and science as a way of knowing. He emphasized the critical importance of introductory science courses in science education and encouraged professional societies to help reshape introductory courses. Alberts also encouraged professional societies to help elevate the importance and prestige of science teaching at all levels, as he has tried to do through editorials and prize contests at Science magazine.

The importance of teaching the nature of science was reiterated by Pennock in his plenary talk, "Synthesis, Reflections, and Moving Forward." By discussing the teaching of evolution both in the historical context of challenges from religious groups and in the context of public understanding of science, Pennock argued that the way to teach evolution more effectively is not by simply presenting more data. Rather, there is a need to first teach evidence-based reasoning: "you cannot just give data to people and expect it to matter if they don't think in an evidence-based way." He also pointed out that while an understanding of the nature of science is needed to understand evolution, discussions of evolution should also be used to teach about the nature of science.

While the arguments presented for teaching evolutionary thinking were compelling, Ross Nehm (Ohio State University) addressed the critical question of effectiveness in his plenary address, "Can This Approach Improve Student Learning of Evolution? The Evidence Base." Summarizing the evidence from an educational research perspective for teaching about evolution across the biology curriculum, Nehm highlighted the fact that there is currently very little direct evidence for the impact of this approach on student learning or student attitudes (Nehm, 2006). However, he pointed out that this is likely due to a dearth of appropriate studies and that evolution education research would benefit from studies employing research designs, such as randomized control trials that enable researchers to make causal claims. What the literature does show is that learning the concepts of evolution is very difficult for students across the academic continuum and that a number of misconceptions persist. Helping students learn about evolution requires a substantive and persistent effort. To begin to tackle problems in evolution education, researchers need to better understand student cognition, including how novices differ from experts in the way they address problems in evolution, and to develop better assessments. Nehm also emphasized that collaboration among the various stakeholders in evolution education will be critical to gather the data needed to move the field forward.

\section{Thinking Evolutionarily: Challenges and Opportunities}

In addition to these plenary addresses, the convocation featured several panel presentations that provided a diversity of perspectives on the challenges and opportunities for the Thinking Evolutionarily initiative. ${ }^{5}$ The first of these panels was Expanding Curricular Opportunities to Introduce Evolutionary Thinking Across the Grade Spans. This panel highlighted the timeliness of this convocation by describing the convergence of several national initiatives and efforts (see

${ }^{5}$ Names of panelists and the topics they discussed are found in the agenda for the convocation: http://nas-sites.org/ thinkingevolutionarily/topics-and-agenda. 
section on A Convergence of Initiatives Calling for Evolution Education) on the idea that evolution should be taught as a fundamental organizing principle and core concept of the life sciences. These include the College Board's evidencecentered redesign of the AP Biology course and examination (College Board, 2011), the national Vision and Change in Undergraduate Biology Education initiative (AAAS, 2011), and the Scientific Foundations for Future Physicians report (AAMC and HHMI, 2009). There was also a brief presentation about the efforts of the NESCent's efforts to advance evolution education through symposia at scientific society conferences, through the efforts of working groups, and by generating educational materials.

In the panel How Can Evolutionary Thinking Help Address the Controversies Surrounding the Teaching of Evolution?: A Faculty Forum, faculty members discussed their perspectives on the challenges and lessons learned in teaching evolution. Building on themes presented earlier, one panelist emphasized that teaching about evolution needs to be closely tied to teaching about the nature of science and that education about evolution needs to begin much earlier than high school. Another panelist pointed out that many students who see evolution as controversial often have a limited understanding of evolution. When introducing evolution in introductory courses, educators should start with examples that are familiar, compelling, motivating, and relevant to students' lives, eventually leading up to an emphasis on the study of evolution as an experimental science. For example, research into topics such as the evolution of behavior, especially reproductive behavior, is particularly compelling for many undergraduates. Another panelist addressing education at the K-12 level discussed how many high school teachers do, in fact, avoid teaching evolution due to fear of encountering challenges from students that they cannot address or pressure from parents or school or district officials. Preservice teachers need to develop a deeper understanding of evolution before entering the classroom.

Another critical issue that was discussed at this convocation is the need for excellent resources for teaching evolutionary thinking in courses throughout the life sciences. The panel Expanding Resources for Teaching Evolutionary Thinking discussed existing resources, how they are growing, and lessons learned in the development of these resources. The Understanding Science website was again touted as a freely available resource to help students and teachers gain a deeper understanding of the processes and nature of science, and panelists echoed earlier discussions of how such understanding is fundamental to understanding evolution. Another panelist suggested that curricular materials need to be designed around how people learn and attend to student motivation. The new high school curriculum supplement from $\mathrm{NIH}$ and the Biological Sciences Curriculum Study (BSCS) entitled Evolution and Medicine (http://science-education .nih.gov/customers.nsf/HSEvolution.htm; Beardsley et al., 2011) and revisions to BSCS Biology: A Human Approach, a textbook that begins with evolution and integrates evolutionary concepts and topics throughout every chapter (BSCS, 2011), were suggested as examples of this more comprehensive approach. A coauthor of the popular high school biology textbook Biology (Miller and Levine, 2010), described how the textbook has been at the center of battles over the teaching of evolution. Some critics have objected to how the book in- fuses evolution throughout. He also described the persistent efforts needed to keep an emphasis on evolution as pressures from the marketplace can dilute the treatment of evolution in textbooks. Another panelist highlighted many freely available resources from Bioquest (see Box 1) for teaching about evolution that place a strong emphasis on having students use and explore authentic data to gain a deeper understanding of evolution and to motivate them to learn more about evolution.

The final panel, Potential Roles of Key Players, brought together several representatives from AIBS, the American Society for Microbiology (ASM), the Federation of American Societies for Experimental Biology (FASEB), and the National Association of Biology Teachers (NABT) to discuss their efforts and the critical roles they play in advancing evolution education. Representatives of AIBS and FASEB emphasized how their umbrella societies have the potential to reach very large audiences that include all the members of their participating societies, as well as the ability to coordinate the efforts of multiple societies that are interested in issues such as teaching evolution. They emphasized the strengths that their organizations bring to science policy and their ability to advocate for the teaching of evolution. Speaking on behalf of individual disciplinary societies, the ASM representative described the four key roles that disciplinary societies fill (advocacy; providing guidelines and models; professional development for members; and information dissemination) and how ASM has used these roles to promote the teaching of evolution. The executive director of NABT emphasized the importance of providing professional development support to help teachers learn how to teach evolution: "one strong teacher... who knows how to address the teaching of evolution. . .can impact change at a local level, and we do not want to underestimate the impacts [that] those teachers can have."

\section{Breakout Sessions and Ideas for Next Steps}

What I think is helpful [about this convocation] is to get different people's perspectives who've done this from the standpoint of website development, from the standpoint of working with K-12 students, from the standpoint of working with the general public, and be able to integrate across all of that.

-Marlene Zuk, University of California, Riverside

The interaction of convocation participants with diverse experiences and ideas with regard to evolution education was a critical component of the meeting. During the first of two breakout sessions, participants were assigned to breakout groups to ensure a diversity of perspectives. Each group was asked to grapple with a particular issue, including: 1) defining and promoting the value of evolutionary thinking; 2) the research base for evolution education (what evidence is needed?); and 3) connecting the Thinking Evolutionarily initiative to other efforts to improve life sciences education. The second set of breakout sessions allowed participants with similar interests and expertise to meet (in self-selected groups) and to formulate ideas for next steps. These groups included: 1) faculty who teach courses in evolution, 2) funders of programs in life sciences education, 3) representatives from professional societies, and 4) curriculum developers and education researchers. During the report of the groups' 
discussions, several ideas presented in the panels and presentations were reiterated, and several additional ideas were presented. Below is a summary of new ideas presented by the breakout groups:

\section{Critical issues in the teaching of evolution}

- Student understanding of statistics and probability, which is required for understanding the underlying data that describe evolutionary processes.

- Teacher understanding of common misconceptions about evolution.

- Development of courses and curricula appropriate for students' ages and developmental stages.

Important considerations and ideas for developing the Thinking Evolutionarily initiative included:

\section{Resource development}

- Create a central resources site that coordinates existing resources for evolution education.

- Develop a searchable database of vetted educational research literature.

- Compile a set of best practices for integrating evolution throughout the life sciences curriculum.

- Develop resources to help assess student understanding of evolution.

\section{Professional development}

- Develop and implement models of successful professional development for teaching evolution.

- Identify sources of funding to allow K-12 teachers to attend professional society meetings and postsecondary faculty who are members of disciplinary societies to attend and present their work on infusing evolution across the life sciences curriculum at professional science education society meetings like NABT.

- Find effective ways to train teachers to teach evolutionary thinking; programs like UTeach at University of Texas, Austin, provide a model. There is a need to create teacher leaders, focusing not only on preservice teachers, but on in-service teachers as well.

\section{Communications and dissemination strategies}

- Key audiences include: 1) Informal groups/citizen groups (Boy Scouts of America, PTAs, citizen science communities, boards of education, etc.); 2) entertainment groups (media, gaming, etc.); and 3) teacher education groups.

- Publish work in this area, and discuss it at various professional venues.

- Take materials to national conferences and disseminate them both to conference participants and members of the local community where the meeting is being held.

- Develop clear messages about the importance of thinking evolutionarily (and thinking scientifically), and mount a campaign to remind those stakeholders who are willing to think and act on this issue to take action.

- Interact with communities and engage them as partners in education.

- Utilize social networking.

\section{SO WHAT? NEXT STEPS}

Since the convocation, many participants have continued the discussions about thinking evolutionarily through a discussion forum website, and several representatives of the professional and disciplinary societies have begun to develop plans for action. As of December 2011, when this article was prepared, leaders of the Coalition of Scientific Societies, ${ }^{6}$ composed of professional and disciplinary societies interested in evolution education, are moving forward on three fronts. First, they are developing a statement about the importance of integrating evolutionary thinking into life sciences curricula that will be signed by participating societies in the coalition and attendees of the Thinking Evolutionarily Convocation. Second, a working group has been formed with the goal of creating a central resource site for Thinking Evolutionarily materials. The group thus far brings together representatives from the Society for Developmental Biology, AIBS, and the Biology Directors Consortium. The coalition is also contemplating ways to provide professional development for society members to learn how to integrate evolutionary concepts into their life sciences courses. The coalition is also planning another Thinking Evolutionarily Trail for the Second USA Science and Engineering Festival Expo, to take place April 28-29, 2012, in Washington, DC, with the participation of several scientific societies.

\section{ACKNOWLEDGMENTS}

The convocation, Thinking Evolutionarily: Evolution Education Across the Life Sciences, which served as the basis for this paper, was generously supported by the Burroughs-Wellcome Fund, the Carnegie Institution for Science, the Christian A. Johnson Endeavor Foundation, NAS, and NSF through a Research Coordination Network/Undergraduate Biology Education grant to Oklahoma University. We thank the other members of the organizing committee for their important contributions to the success of the convocation: Drs. Cynthia Beall (Committee Chair, Member, NAS, Case Western University), James Collins (Arizona State University), Ida Chow (Society for Developmental Biology), Irene Eckstrand (NIH), Kristin Jenkins (NESCent), and Nancy Moran (Member, NAS, Yale University). We also thank Gordon Uno (Oklahoma University), who served as a volunteer special consultant to the committee.

\section{REFERENCES}

American Association for the Advancement of Science (2011).Vision and Change in Undergraduate Biology Education: A Call to Action. http://visionandchange.org/files/2011/03/VC-Brochure-V6-3.pdf (accessed 9 December 2011).

Association of American Medical Colleges and Howard Hughes Medical Institute (2009). Scientific Foundations for Future Physicians Report of the AAMC-HHMI Committee. www.hhmi.org/ grants/pdf/08-209_AAMC-HHMI_report.pdf (accessed 9 December 2011).

Beardsley PM, Stuhlsatz MAM, Kruse R, Eckstrand IA, Gordon SD, Odenwald WF (2011). Evolution and medicine: an inquiry-based

\footnotetext{
${ }^{6}$ Additional information is available at www.faseb.org/Policy-and -Government-Affairs/Science-Policy-Issues/Evolution-Education -Resources/Coalition-of-Scientific-Societies.aspx.
} 
high school curriculum supplement. Evolution: Education and Outreach 4, 603-612.

BSCS (2011). BSCS Biology: A Human Approach, 4th ed., Dubuque, IA: Kendall Hunt.

College Board (2011). AP Biology Curriculum Framework, 20122013. http://media.collegeboard.com/digitalServices / pdf/ap /10b 2727_AP_Biology_CF_WEB_110128.pdf (accessed 9 December 2011).

Dobzhanksy T (1973). Nothing in biology makes sense except in the light of evolution. Am Biol Teach 35, 125-129.

Miller K, Levine J (2010). Biology, New York: Pearson.

National Academy of Sciences and Institute of Medicine (2008). Science, Evolution, and Creationism, Washington, DC: National Academies Press. www.nap.edu/sec (accessed 20 January 2012).

National Research Council (NRC) (1996) National Science Education Standards, Washington, DC: National Academies Press. www.nap.edu/catalog.php?record_id=4962 (accessed 20 January 2012).

NRC (2002). Learning and Understanding: Improving Advanced Study of Mathematics and Science in U.S. High Schools, Washington, DC: National Academies Press. www.nap.edu/ catalog.php?record_id=10129 (accessed 20 January 2012).

NRC (2011). A Framework for K-12 Science Education: Practices, Crosscutting Concepts, and Core Ideas, Washington, DC: National Academies Press. www.nap.edu/catalog.php?record_id=13165 (accessed 20 January 2012).

Nehm RH (2006). Faith-based evolution education? Bioscience 56, 638-639.

Nehm RH, Poole TM, Lyford ME, Hoskins SG, Carruth L, Ewers $\mathrm{BE}$, Colberg PJS (2009). Does the segregation of evolution in biology textbooks and introductory courses reinforce students' faulty mental models of biology and evolution? Evolution: Education and Outreach $2,527-532$. 